\title{
Parasite-host relationship between the tambaqui (Colossoma macropomum Cuvier 1818) and ectoparasites, collected from fish farms in the City of Rolim de Moura, State of Rondônia, Western Amazon, Brazil
}

\author{
Mara Maria Izar de Maio GODOI ${ }^{1}$, Vera ENGRACIA ${ }^{2,3}$, Maria de Los Angeles Perez LIZAMA ${ }^{4}$, \\ Ricardo Massato TAKEMOTO5
}

\section{ABSTRACT}

In this study we investigated the relationship between tambaqui fish (Colossoma macropomum Cuvier 1818) and parasites in two fish farms (L204S and L180N) in the state of Rondônia, Brazil, during a 1-year period. The objective of the study was to describe the relationships between parasites, hosts and the environment. From the 80 fish specimens collected, 100\% were parasitized by at least one parasite species. Seven ectoparasites species were recorded, six of the class Monogenea: Anacanthorus spathulatus, Mymarothecium spp. (Mymarothecium sp. 1, Mymarothecium sp. 2 and M. viatorum), Notozothecium sp. and Linguadactyloides brinkimanni, classified as dominants, and the copepod Perulernaea gamitanae, classified as subordinate. Despite their high prevalence, the parasites were not abundant. A. spathulatus presented positive and significant correlations between the abundance of parasitism and the standard length of the hosts in the two fish farms; Mymarothecium spp. showed significant correlations, negative in L180N, and positive in L204S; significant positive correlations were observed for Notozothecium sp. in L204S, and for L.brinkimanni in L180N. Young monogeneans were found; these parasites presented a negative correlation in L180N and a significant negative correlation in L204S. The results of the correlation between the relative condition factor (Kn) and the abundance of parasites were not significant for the recorded parasite species. Regarding the hepatosomatic relation (HSR) of fish and the abundance of parasites, Anacanthorus spathulatus showed a significant negative correlation with the HSR in L180N, and a positive correlation in L204S. Mymarothecium spp. and Notozothecium sp. presented significant positive correlations in L204S. Considering the correlation of the fish splenosomatic relation (SSR) and the abundance of parasites, L. brinkimanni presented significant correlations, positive in L180N and negative in L204S. Despite 100\% prevalence, the high water quality contributes to infracommunities with low parasite abundance and good levels of Kn, HSR and SSR, allowing good tambaqui development. KEYWORDS: fish farms, tambaqui, parasites, ecological relationships.

\section{Relação parasito-hospedeiro tambaqui (Colossoma macropomum Cuvier 1818) e ectoparasitos coletados em pisciculturas do município de Rolim de Moura, no estado de Rondônia, Amazônia Ocidental, Brasil}

\section{RESUMO}

Neste estudo foram investigadas as relaçóes entre o peixe tambaqui (Colossoma macropomum Cuvier 1818), e parasitos em duas pisciculturas (L204S e L180N) no estado de Rondônia, Brasil, durante o período de um ano, com o objetivo de descrever as relaçóes entre parasitos, hospedeiros e meio ambiente. Dos 80 espécimes coletados, 100\% estavam parasitados por pelo menos uma espécie de parasito. Sete espécies de ectoparasitos foram registradas, seis Monogenea: Anacanthorus spathulatus, Mymarothecium (Mymarothecium sp. 1, Mymarothecium sp. 2 e M. viatorum), Notozothecium sp. e Linguadactyloides brinkimanni, classificadas como dominantes e o copépode Perulernaea gamitanae, classificado como subordinado. Apesar da alta prevalência, os parasitos foram pouco abundantes. A abundância de parasitismo por $A$. spathulatus e o comprimento-padráo do hospedeiro apresentou correlação positiva nas duas pisciculturas; Mymarothecium spp apresentou correlação negativa na L180N e positiva na L204S; Notozothecium sp. apresentou correlação positiva na L204S; L. brinkimanni apresentou correlaçáo positiva na L180N. Monogenóides jovens apresentaram correlaçáo negativa nas duas pisciculturas. Os resultados do fator de condição relativo (Kn) em relação à abundância de parasitismo nâo foram significativos em nenhuma das espécies de parasitos. Houve correlação negativa entre a relação hepatossomatica (RHS) e abundância de $A$. spathulatus na L180N e positiva na L240S. Mymarothecium spp. e Notozothecium sp. apresentaram correlação positiva na L204S. Correlação positiva entre a RHS e abundância de L. brinkimanni foi observada na L180N e negativa na L204S. Apesar de 100\% de prevalência, a boa qualidade da água contribuiu para que a infracomunidade apresenta-se abundância parasitaria baixa e bons índices de Kn, RHS e SSR possibilitando bom desenvolvimento dos tambaquis.

PALAVRAS-CHAVE: piscicultura, tambaqui, parasitos, relaçôes ecológicas.

\footnotetext{
${ }_{1}^{1}$ Universidade Federal de Rondônia, PGBIOEXP- Post-graduation in Experimental Biology. Av Norte sul, n 7800, Nova Morada, Rolim de Moura, R0-Brazil. e-mail: mara.godoi@gmail.com 2 Universidade Federal de Rondônia, PGBIOEXP - Post-graduation in Experimental Biology. Br 364, Km 9,5 sentido Acre, Porto Velho, R0-Brazil. e-mail: engracia.oliveira@uol.com.br ${ }_{3}^{3}$ Intituto de Pesquisa em Doenças Tropicais, IPEPATRO, BR 364, Km 3.5, 78900-970 Porto Velho, RO-Brazil.

Universidade Estadual de Maringá - Laboratory of Ichthyoparasitology. Av. Colombo, 5790, G90 - Maringá, PR - Brazil. e-mail: lizamamdla@yahoo.com.br

5 Universidade Estadual de Maringá - Laboratory of Ichthyoparasitology. Av. Colombo, 5790, G90 - Maringá, PR - Brazil. e-mail: takemotorm@nupelia.uem.br
} 


\section{INTRODUCTION}

The development and spreading of fish farms in the region of Rondônia have not been followed by studies on diseases that may occur in cultured fish. Among several problems, parasitic diseases can cause high mortality, resulting in great economic losses (Pavanelli et al. 1998).

Tambaqui fish, Colossoma macropomum Cuvier 1818 (Characiformes: Characidae), are found in the basins of the Rivers Orinoco and Amazonas, in the northern and northeastern regions of Brazil. The species reaches a maximum length of $100 \mathrm{~cm}$ and up to $30 \mathrm{~kg}$ in total weight. These fish are planktivorous from the larval to the adult stage, eating fruits, seeds and shellfish during the adult phase. In captivity, ration, grains and agricultural and industrial products are well accepted. They grow quickly, reaching 700 to $900 \mathrm{~g}$ or more in the first year of cultivation, and 1.5 to $3 \mathrm{~kg}$ or more in the second year. Because of these individual characteristics of conversion rate and feeding habits, the adaptation of this species to captivity is consolidated. Being a species that presents delicious meat, which is well accepted by consumers, great economic success has been achieved (EMATER-RO 2006).

One of the main problems in fish farms is the lack of data regarding the diagnosis of parasitic diseases in fish, making it difficult to treat diseases by prophylactic and therapeutic procedures.

In Brazil, diagnostic studies have been carried out. One of these studies was performed by Tavares-Dias et al. (2001), who investigated parasitic fauna of fish from a fee fishing farm located in Franca, São Paulo State by measuring the degree of relative susceptibility of hosts to parasites. Fish specimens examined were: piauçú Leporinus macrocephalus Garavello \& Britski, 1988 (Anostomidae), pacu Piaractus mesopotamicus Holmberg, 1887 (Characidae), carp Cyprinus carpio Linnaeus, 1758 (Cyprinidae), Tillapia rendalli Boulenger, 1896 (Cichlidae), Nile tilapia Oreochromis niloticus Linnaeus, 1758 (Cichlidae), matrinxã Brycon cephalus Glinther, 1869 (Characidae) and tambacu hybrid (male of P. mesopotamicus $\times$ female of C. macropomum Cuvier, 1818). Ghiraldelli et al. (2006) studied ectoparasites from Oreochomis niloticus cultivated in the State of Santa Catarina, Brazil; in this paper the authors discussed the importance of the environment in the composition of ectoparasite communities. However, Martins et al. (2009), who studied the influence of parasitic fauna in the production system of Nile tilapias, showed that low stocking density and low water temperature in the same region were responsible for the maintenance of good health and lower parasitism rate.
Regarding this, the objective of this study was to describe the relationships between parasites, hosts and the environment, in order to improve fish quality.

\section{MATERIALS AND METHODS}

The fish used in this study were collected monthly, between March 2009 and March 2010, from two fish farms in the City of Rolim de Moura, State of Rondônia, Brazil (Figure. 1). One of the fish farms is located at 204 South Line (L204S; 110 49' 24.52" S, 610 $\left.36^{\prime} 05.36^{\prime \prime} \mathrm{W}\right)$; the other is at 180 North Line (L180N; 110 42' 55.63" S, 610 41' 05.00” W). The system of local fish farming is semi-intensive. We collected 80 fish, 47 fish from L180N and 33 fish from L204S during the year.

The fish farm L180N promotes the fattening and marketing of fish, while the fish farm L204S, in addition to these goals, is also used for fee fishing at weekends.

After collection, fish were anaesthetized with benzocaine (3 g benzocaine: $20 \mathrm{ml}$ methanol $99.6{ }^{\circ} \mathrm{GL}$ : 30 liters of water) and killed by a decrease in temperature. The body, fins, nostrils, mouth, eyes and the inner surface of the opercula were immediately examined for parasites, stored at $-4^{\circ} \mathrm{C}$, and then transported to the Laboratory of Ichthyoparasitology of the Federal University of Rondônia, in the campus of Rolim de Moura, where they were stored at $-12^{\circ} \mathrm{C}$. Date of sampling, collection site, standard length $(\mathrm{cm})$, total length $(\mathrm{cm})$, total weight $(\mathrm{g})$, spleen weight $(\mathrm{g})$ and liver weight $(\mathrm{g})$ of each fish were recorded. It was not possible to identify the sex of the fish, because the maturation of young tambaqui happens when $50 \%$ of the population reaches about 45 to $60 \mathrm{~cm}$ of standard length, or 4 years old. Specimens used in this study were collected before they had grown to this size (Araujo-Lima and Goulding 1997).

After that, the gills and viscera were removed and processed, and their parasites were collected and fixed

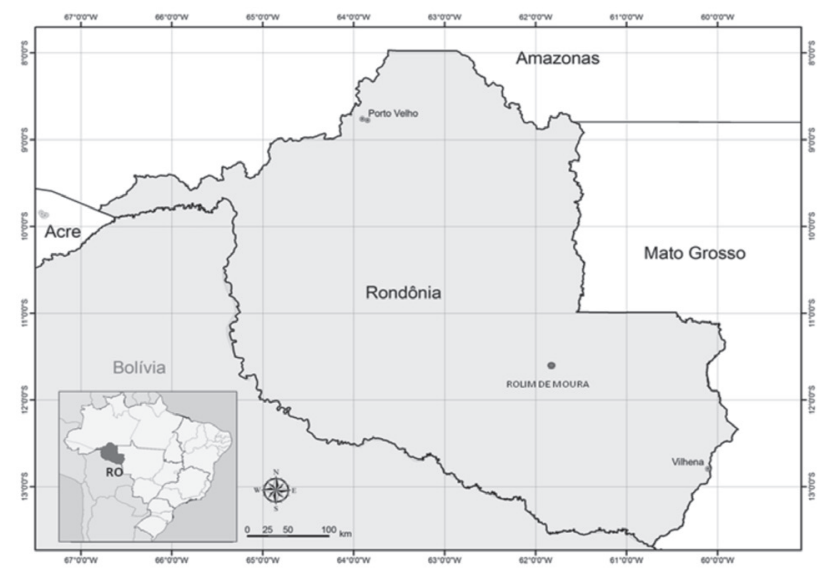

Figure 1 - City of Rolim de Moura, State of Rondônia, Brazil (modified from EMBRAPA 2011). 
according to Eiras et al. (2006). Terminology related to parasite ecology was based on Bush et al. (1997).

\section{Characteristics of the hosts}

The values of $a$ and $b$, obtained by the weight/length ratio, were used to estimate the expected values of body weight (We) using the expression $\mathrm{We}=\mathrm{a} \times \mathrm{Ls}^{\mathrm{b}}(\mathrm{LeCren} 1951)$. The relative condition factor $(\mathrm{Kn})$ was calculated using the observed/ expected weight ratio for a given length $(\mathrm{Kn}=\mathrm{Wo} / \mathrm{We})$, with the aim to detect differences in the welfare of parasitized hosts.

The hepatosomatic relation (HSR) and splenosomatic relation (SSR) were estimated by the expressions $\mathrm{HSR} \%=$ liver weight $(\mathrm{g}) /$ body weight $(\mathrm{g}) \times 100$, and SSR $\%=$ spleen weight $(\mathrm{g}) /$ body weight $(\mathrm{g}) \times 100$, respectively.

\section{Water quality}

Water samples were collected from varied tanks in each fish farm throughout the year of research. The limnological parameters analysed were $\mathrm{pH}$, alkalinity, total hardness amount of dissolved oxygen (CK), transparency, ammonia and water temperature. For both samples, water was collected from the pond after the fish had been removed. The sample was collected from a point near the drainage system (monk), packaged in plastic tubes and transported to the EMATERRO laboratory for analysis of chemical reactions by means of specific methodology, and compared with established colour standards. For the parameters dissolved oxygen, temperature and conductivity we used digital equipment (MO-880, TH1300-860 and CD, respectively). Analysis was carried out directly in the $10 \mathrm{~cm}$-deep water of the ponds; the recorded values were compared with values proposed by Araujo-Lima and Goulding (1997).

\section{Statistical analysis}

Spearman's rank correlation coefficient $(r s)$ was used to determine the correlation between the abundance of infestation and the standard length of the host, HSR, SSR and $\mathrm{Kn}$. The level of significance adopted was $p<0.05$. The Kruskal-Wallis test was used to detect changes in the abundance of parasites in different seasons. To characterize the importance of each parasites species in the community, the importance value proposed by Bush (I) was used (Thul et al. 1985).

\section{RESULTS AND DISCUSSION}

Tambaqui, C. macropomum Cuvier 1818 is a native species used in the State of Rondônia as an economic source, because of its planktivorous habit from the larval to the adult stage. They usually feed more on fruit, seeds and shellfish during the adult phase. Fish adaptation to captivity follows individual characteristics such as conversion rate and feeding habits, leading to economic success (EMATER-RO 2006).

The hosts had total length between 20.0 and $54.3 \mathrm{~cm}$ $($ mean $=34.99 \pm 7.9 \mathrm{~cm})$; standard length ranged from 16.0 to $44.50 \mathrm{~cm}$ (mean $=28.6 \pm 6.8 \mathrm{~cm})$. Total weight ranged between 136 and 2,868 $\mathrm{g}$ (mean $=907 \pm 0.82 \mathrm{~g}$ ). These values did not differ between the facilities.

\section{Water quality}

The physical and chemical characteristics of the water where the tambaquis were confined are summarized in table 1.

Regarding $\mathrm{pH}$, samples were taken in different periods, and the values found in both farms were considered slightly acidic, with $\mathrm{pH}$ ranging from 6.0 to 6.9. These values are in accordance with Aride et al. (2004), who observed that the best growth of tambaqui occurs in acidic water with $\mathrm{pH}$ between 4.0 and 6.0.

Although the values found are temporally more alkaline than appropriate, they did not cause fish mortality. The alkalinity ranged from 40 to $60 \mathrm{mgl}^{-1}$ in L180N, and 30 to $35 \mathrm{mgl}^{-1}$ in L204S. The best values of alkalinity for growth of tambaqui have not been determined so far, but in the State of Amazonas the production systems of tambaqui present water with very low values $\left(1-10 \mathrm{mgl}^{-1}\right)$ when the setting is not performed, and $40 \mathrm{mgl}^{-1}$ when the setting is performed (Gomes et al. 2010).

The hardness found in L204S was 50 parts per million (ppm). The value of $70 \mathrm{ppm}$ was also observed, three times

Table 1 - Physical and chemical characteristics of water in the fish farms L204S and L180N, in the City of Rolim de Moura, State of Rondônia, Brazil.

\begin{tabular}{|c|c|c|c|c|c|c|c|c|}
\hline \multirow[b]{2}{*}{ Line } & \multicolumn{2}{|c|}{ March 2009} & \multicolumn{2}{|c|}{ July 2009} & \multicolumn{2}{|c|}{ November 2009} & \multicolumn{2}{|c|}{ March 2010} \\
\hline & L204S & L180N & L204S & L180N & L204S & L180N & L204S & L180N \\
\hline $\mathrm{pH}$ & 6.9 & 6.0 & 6.1 & 6.3 & 6.0 & 6.5 & 6.1 & 6.9 \\
\hline Alkalinity. $\left(\mathrm{mgl}^{-1}\right)$ & 60 & 30 & 45 & 35 & 50 & 35 & 40 & 35 \\
\hline Total hardness(ppm) & 70 & 40 & 50 & 40 & 50 & 40 & 50 & 40 \\
\hline Dissolved $\mathrm{O}_{2}\left(\mathrm{mgl}^{-1}\right)$ & $4-6$ & $3-6$ & $4-6$ & $3-6$ & $4-6$ & $3-6$ & $4-6$ & $3-6$ \\
\hline Transparency (cm) & 30 to 40 & 30 to 50 & 30 to 40 & 30 to 50 & 30 to 40 & 30 to 50 & 30 ato 40 & 30 to 50 \\
\hline Ammonia $\left(\mathrm{mgl}^{-1}\right)$ & $<1$ & $<1$ & $<1$ & $<1$ & $<1$ & $<1$ & $<1$ & $<1$ \\
\hline Water Temperature $\left({ }^{\circ} \mathrm{C}\right)$ & 26 & 25 & 20 & 21 & 27 & 26 & 25 & 25 \\
\hline
\end{tabular}


higher than what is considered appropriate, but no injuries or disorders were observed in the development of fish. In L180N, the hardness was $40 \mathrm{ppm}$, twice that considered as adequate. The recommended values for good water quality are greater than 20 ppm (Izel and Melo 2004).

Both fish farms showed dissolved oxygen between 3.0 and $6.0 \mathrm{mg} \mathrm{L}^{-1}$. Since the tambaqui is resistant to hypoxia and can be supported by values below $1.0 \mathrm{mg} \mathrm{L}^{-1}$ (Saint-Paul 1984), the levels of oxygen observed in the facilities were considered appropriate.

The values found for ammonia were below $1.0 \mathrm{mgL}^{-1}$. The tambaqui is resistant to the toxic effect of ammonia, and concentrations up to $0.46 \mathrm{mgL}^{-1}$ of non-ionized ammonia (ammonia toxic state) do not compromise the growth of the species (Ismiño-Orbe et al. 2003). We believe that the values observed in this study did not affect the development of the fish. The water temperature during the studied period was between 20 and $27^{\circ} \mathrm{C}$. According to Garcia et al. (2008), tambaquis are less resistant to temperatures lower than 18 ${ }^{\circ} \mathrm{C}$. This temperature rarely occurs in the State of Rondônia.

Being a rough fish, tambaqui tolerates variations in the water quality. In its natural environment, it is found in waters rich in nutrients such as the Amazonas River, but it is also found in poor waters, such as found in the Negro River.

It might be recommended to maintain a strong control of water quality, such as $\mathrm{pH}$, temperature, oxygen level, water flow in the tanks and population density. The adequate transport of fish is also a significant factor, because stress and injury can facilitate various infections.

The values showed good water quality in both fish farms, this being a major factor in the development of fish.

\section{Parasite fauna of Colossoma macropomum}

At least 20 parasite species were identified in the tambaqui (Eiras et al. 2010), excluding pathogenic bacteria and fungi. Tambaqui is a relatively robust species and resists parasite infestation well. However, some infestations seriously compromise the performance and growth of cultured fish. The main parasites recorded for tambaqui are: the monogeneans Anacanthorus spathulatus Kritsky, Thatcher \& Kayton 1979, A. penilabiatus Boeger, Husak \& Martins 1995, Notozotheciun janauachensis Belmont-Jegu, Domingues \& Martins 2004, Linguadactyloides brinkmanni Thatcher \& Kritsky, 1983 and Mymarothecium boegeri Cohen \& Kohn 2005; one digenean of the family Paramphistomidae (Fischer et al. 2003); a plerocercoid larva of Cestoda from the family Proteocephalidae (Békési 1992); the isopod Braga sp.; the nematodes Spirocamallanus inopinatus Travassos 1929, Spirocamallanus spp. (Ferraz 1995), Chabaudinema americana Diaz-Ungria 1968, Cucullanus colossomi Diaz-Ungria 1968, and Procamallanus sp. (Fischer et al. 2003); the branchiurans
Dolops carvalhoi Castro 1949, Argulus chicomendesi Malta \& Varella 2000 (Malta and Varella 2000) and A. multicolor Stekhoven 1937; the copepods Gamidactylus jaraquensis Thatcher \& Boeger 1984 (Fischer et al. 2003) and Perulernaea gamitanae Thatcher \& Paredes 1985 (Benetton and Malta 1999); the myxosporidean Henneguya piaractus Martins \& Souza 1997, and the ciliated protozoan Ichthyophthirius multifiliis Fouquet 1876.

In the present study, 3,789 parasites were collected in $C$. macropomum. The parasites belong to seven taxa, from two groups of metazoans: Monogenea and Crustacea (table 2). The average number of parasite species per gill was 6.8 , with a mean abundance of 47.3625 . The monogeneans represented $99.6 \%$ of the analysed parasites, and constitute the group with the highest species richness in the studied fish farms. Anacanthorus spathulatus and Notozothecium sp. contributed to $69.7 \%$ of the parasites collected. Prevalence of parasitism in fish collected from the fish farms was $100 \%$, i.e., all the examined fish were parasitized (table 2). No parasites were found in the guts.

Regarding the species Mymarothecium spp., three species were recorded: Mymarothecium sp.1, Mymarothecium sp. 2 and M. viatorum. Young forms of Monogenea were considered the parasites that presented morphological characteristics according to the class Monogenea, but did not show developed internal organs, such as the male copulatory complex.

Comparing the results from the two fish farms (table 2), the parasites collected in L204S showed a higher intensity of infestation, contributing to 2006 parasites (51.9\%), with a mean of 8.7. The highest parasite intensity was found in L204S, with 276 specimens of Notozothecium sp. collected in just one fish. In L180N, 1811 parasites were collected (48.1\%), with a mean of 5.552. The highest parasite intensity found in L180N was for A. spathulatus, with 101 parasites in just one specimen of tambaqui.

Anacanthorus spathulatus is considered pathogenic and can cause a decrease in the host's respiratory capacity. This parasite deserves special attention, because of its presence in most reared tambaquis, always presenting high parasitic levels when compared with other species of monogeneans (Morais et al. 2009).

Anacanthorus spathulatus was considered common, with a high prevalence and low mean intensity (table 2) in the two facilities studied. These parasites showed the same morphological characteristics described by Kritsky et al. (1992), who reported the presence of Anacanthorus Mizelle \& Price 1965 from C. macropomum collected in Lake Janauacá, Amazon, Brazil.

Mymarothecium spp. were common and presented low to medium intensity. Notozothecium sp., despite being found at 
Table 2 - Number of infested fish (IF), number of collected parasites (CP), prevalence (P\%) $\left({ }^{c}=\right.$ common, ${ }^{r}=$ rare, ${ }^{i}=$ intermediate), mean abundance (MA) and mean intensity (MI) $\left({ }^{\mathrm{ll}}=\right.$ very low, ${ }^{\mathrm{l}}=\mathrm{low},{ }^{\mathrm{h}}=$ high) of parasitic fauna in Colossoma macropomum captured in fish farms in the City of Rolim de Moura, State of Rondônia, Brazil / RO.

\begin{tabular}{|c|c|c|c|c|c|c|c|c|c|c|}
\hline \multirow{2}{*}{$\begin{array}{l}\text { Fish farm } \\
\text { Parasite }\end{array}$} & \multicolumn{6}{|c|}{ L180N } & \multicolumn{2}{|c|}{ L204S } & \multirow[b]{2}{*}{ MA } & \multirow[b]{2}{*}{$\mathrm{MI}$} \\
\hline & $\mathrm{IF}$ & $\mathrm{CP}$ & $\mathrm{P} \%$ & MA & $\mathrm{Ml}$ & IF & $\mathrm{CP}$ & $\mathrm{P} \%$ & & \\
\hline \multicolumn{11}{|l|}{ Monogenea } \\
\hline A. spathulatus & 44 & 694 & $93^{c}$ & 8.67 & $15.7^{1}$ & 32 & 476 & $96^{c}$ & 5.95 & $14.87^{\prime}$ \\
\hline Mymarothecium spp. & 22 & 379 & $46^{i}$ & 4.7 & $17.2^{1}$ & 21 & 401 & $93^{c}$ & 5.0 & $19.09^{\prime}$ \\
\hline Notozothecium sp. & 37 & 534 & $79^{\circ}$ & 6.67 & $14.4^{\prime}$ & 31 & 943 & $94^{c}$ & 11.7 & 30.12 \\
\hline L. brinkimanni. & 39 & 174 & $76^{c}$ & 2.17 & $4.46^{\mathrm{vl}}$ & 15 & 111 & $13.5^{i}$ & 1.38 & $7.4^{\mathrm{vl}}$ \\
\hline Monogenea young forms & 3 & 29 & $6.3^{r}$ & 0.36 & $9.6^{v 1}$ & 6 & 42 & $18.9^{i}$ & 0.5 & $7^{\mathrm{vI}}$ \\
\hline \multicolumn{11}{|l|}{ Crustacea } \\
\hline P. gamitanae & 1 & 1 & $2.2^{r}$ & 1 & - & 6 & 33 & $18.2^{i}$ & 0.4 & $5.5^{\mathrm{vl}}$ \\
\hline
\end{tabular}

Common $(P>50 \%)$, intermediate $(10 \% \leq P \leq 50 \%)$, rare $(P<10 \%)$. (very low $=M l<10$, low $=10 \leq M I \leq 50$, high $=M l>100)$.

the highest abundance in L204S, was common and presented low to medium intensity in the fish farms studied. Although these parasites are found in large quantities, no damage to the growth and development of fish was observed.

The monogenean Linguadactyloides brinkimanni was common, but its mean intensity was considered very low in this study. According to Thatcher (2006), this species occurs always in juveniles of more than $15 \mathrm{~cm}$ standard length, which was confirmed in this study. With its flat shape, the parasite stays fixed on the gill filaments, often anchored to the cartilaginous tissue, and the infected tissue grows around the parasite, fixing it permanently. Once fixed, the parasite feeds on blood and the epithelium of the gills, causing secondary infections and destruction of the gill filament (Thatcher 2006).

One species of crustacean was found, Perulernaea gamitanae Thatcher \& Paredes 1985 (Crustacea: Cyclopoida: Lernaeidae). Unlike other parasites, this species is rare and had a very low mean intensity. This parasite is found in the Amazon region and its description was based on species found in Iquitos, Peru; the same species has also been found in the vicinity of Manaus, Brazil. This parasite can cause problems in fish farms, because it may be responsible for heavy infestations, leading to secondary infections and causing high mortality of hosts (Thatcher 2006).

By analysing the relationship between abundance and number of parasites in the fish farms studied, it was observed that $A$. spathulatus was more abundant in $\mathrm{L} 180 \mathrm{~N}$ and Notozothecium sp. was two times more abundant in L204S; however, this difference was not significant. For Mymarothecium spp., L. brinkimanni and young forms of monogeneans, the abundances between the facilities were very similar (Figure 2).

Regarding prevalence (Figure 3), specimens of $A$. spathulatus showed similar numbers in both fish farms. Mymarothecium spp. was twice as prevalent in L204S, L. brinkimanni was more prevalent in L180N, and the species
Notozothecium sp., Mymarothecium spp., young forms of monogeneans and the crustacean $P$. gamitanae were more prevalent in L204N. In fact, this shows that the fish farms presented similar peculiarities.

The presence of monogeneans in a particular host, i.e. host specificity, can be influenced by numerous factors, including different fixing strategies that are related to mechanical and chemical factors that stimulate the permanence of these parasites on their hosts. The mucous cells of the hosts contain proteins, polypeptides and carbohydrates that are recognized

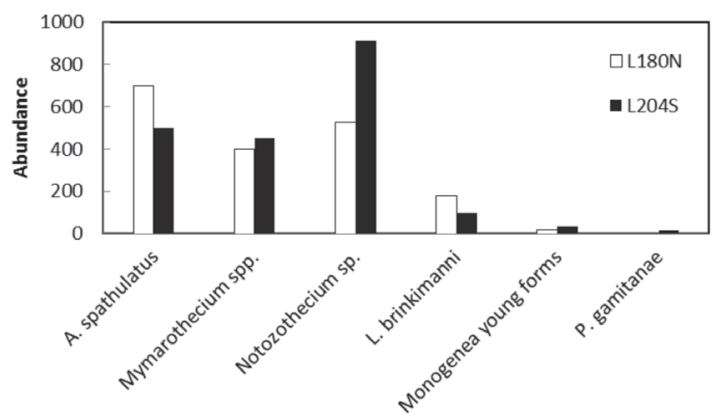

Figure 2 - Abundance of parasites in Colossoma macropomum collected from two fish farms in the City of Rolim de Moura, Western Amazon.

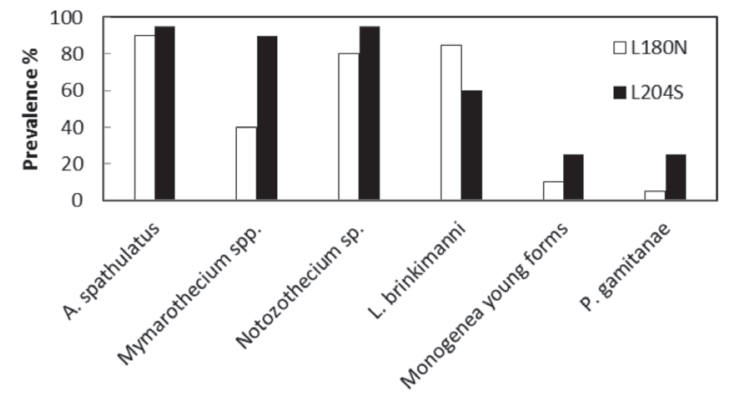

Figure 3 - Prevalence of parasites in Colossoma macropomum collected from two fish farms in the City of Rolim de Moura, Western Amazon, Brazil. 
by the parasite, facilitating the encounter between the two (Buchmann and Lindestron 2002).

This paper records the first occurrence in the state of Rondônia the monogeneans Anacanthorus spathulatus, Linguadactyloides brinkmanni, Mymarothecium viatorum and the copepod Perulernaea gamitanae.

This paper records the first occurrence in the tambaqui the monogenean Mymarothecium viatorum, and reports two new species, Mymarothecium sp. 1 and Mymarothecium sp. 2, of $C$. macropomum monogenea parasites.

\section{Parasitism and seasonality}

The climate in the City of Rolim de Moura is equatorial, with variation of being tropically hot and humid. The annual precipitation is high, ranging between 2000 and $2500 \mathrm{~mm} /$ year, with dry and rainy seasons well defined (Fernandes and Guimarães 2002). In this study, the dry season from April to September corresponds to autumn and winter, and the rainy season from October to March corresponds to spring and summer. Most of the rainfall occurs from January to March.

Comparing the abundance of parasitism with seasonality in the facilities, the Kruskal-Wallis test showed significant differences for $A$. spathulatus, Mymarothecium spp., Notozothecium sp. and L. binkimanni (table 3). Applying Dunn's comparison method, it was observed that the abundance of $A$. spathulatus was seven times higher during the drought of 2009 than in the rainy season of the same year, and five times higher than in the rainy season of 2009-10. For Mymarothecium spp. and Notozothecium sp. the abundance was higher during the dry season of 2009, and for L. binkimanni the abundance was higher during the rainy season of 2009 (Figure 4).

Notozothecium sp., A. spathulatus and Mymarothecium spp. had their highest abundance during the dry period. Notozothecium sp. was more abundant also during the rainy season of 2009. The results showed that species were abundant in the dry season.

Figure 5 presents the variations in prevalence for the six taxa of species of parasites during the regional seasonal variation.

The results showed that the highest prevalence was found for $A$. spathulatus in the dry season of 2009 and the rainy season of 2009-10. Mymarothecium spp. were more prevalent in rainy seasons; Nothozothecium sp. was prevalent throughout the sampling period, particularly during the rainy season; $L$. brinkimanni and $P$. gamitanae were four times more prevalent in the rainy season of 2009 and young forms of monogeneans were three times more prevalent in the rainy season of 2009.

Prevalences remained high for most species during the rainy season of 2009. According to Paperna (1963), most species of Monogenea follow a well-defined annual infestation pattern, increasing in intensity in summer and decreasing in winter. In this study we considered autumn and winter as the dry season (April to September), and spring and summer as the rainy season (October to March). Thus we can consider that monogeneans followed the infestation pattern, with the highest prevalences in the summer.

The results showed that most monogeneans were more prevalent in the rainy periods, but the abundance did not follow the same pattern, as the highest values occurred in the dry season. Despite the high prevalence, the abundance was not sufficient to cause damage.

\section{Total length}

Anacanthorus spathulatus presented positive and significant correlations between the abundance of parasitism and the total length of the host in the two fish farms. The species Mymarothecium spp. and Notozothecium sp. showed a significant positive correlation in L204S, and L. brinkimanni presented a significant positive correlation in the $\mathrm{L} 180 \mathrm{~N}$ (table 4).

Table 3 - Kruskal-Wallis test comparing the abundance of parasitism by seasonality, in Colossoma macropomun captured from two fish farms (L204S and L180N) in the City of Rolim de Moura, between March 2009 and March $2010(p \leq 0.05)$

\begin{tabular}{lcc}
\hline Parasites & $\mathrm{H}$ & $\mathrm{p}$ \\
\hline Monogenea & & \\
Anacanthorus spathulatus & 9.5986 & $0.0082^{*}$ \\
Mymarothecium spp. & 15.4100 & $0.0005^{\star}$ \\
Notozothecium sp. & 24.1569 & $0.0000^{*}$ \\
Linguadactyloides brinkimanni & 13.8415 & $0.0010^{*}$ \\
Monogenea young forms & 4.7491 & 0.0931 \\
\hline Crustacea & & \\
Perulernaea gamitanae & 3.6753 & 0.1592 \\
\hline
\end{tabular}

* Significant values.

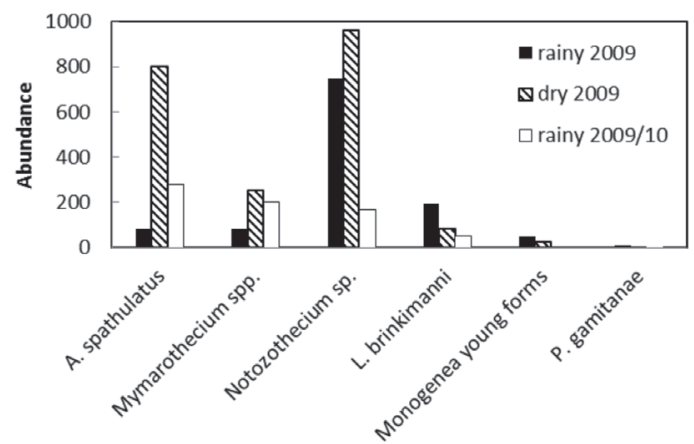

Figure 4 - Seasonal variation in the abundance of parasites in Colossoma macropomum collected from two fish farms (L204S and L180N) in the City of Rolim de Moura, in the rainy seasons (from January to April 2009, and October 2009 to March 2010), and the dry season (from May to September 2009). 


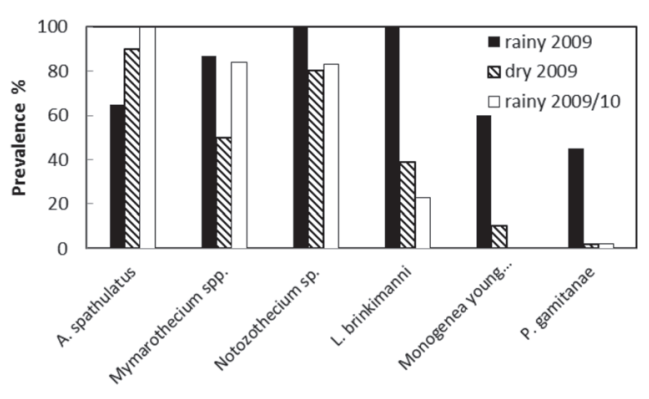

Figure 5 - Seasonal variation in the prevalence (\%) of parasites of Colossoma macropomum collected from two fish farms (L204S and L180N) in the City of Rolim de Moura, in the rainy seasons (from January to April 2009, and October 2009 to March 2010), and the dry season (from May to September 2009).

Table 4 - Spearman's rank correlation coefficient (rs), correlating total length with the abundance of parasitism for 80 specimens of Colossoma macropomum captured in fish farms (L204S and L180N) in the City of Rolim de Moura between March 2009 and March 2010.

\begin{tabular}{lcccc}
\hline \multirow{2}{*}{$\begin{array}{l}\text { Fish farms } \\
\text { Parasite }\end{array}$} & \multicolumn{2}{c}{ L180N } & \multicolumn{2}{c}{ L204S } \\
\cline { 2 - 5 } & rs & $\mathrm{p}$ & rs & $\mathrm{p}$ \\
\hline Monogenea & & & & \\
Anacanthorus spathulatus & 0.4173 & $0.0035^{\star}$ & 0.3668 & $0.0357^{*}$ \\
Mymarothecium spp. & -0.2868 & 0.0506 & 0.3979 & $0.0218^{*}$ \\
Notozothecium sp. & 0.2042 & 0.1684 & 0.4004 & $0.0209^{*}$ \\
Linguadactyloides brinkimanni & 0.3724 & $0.0099^{*}$ & 0.0797 & 0.6594 \\
Monogenea young forms & -0.2868 & 0.0506 & -0.3979 & $0.0218^{*}$ \\
\hline
\end{tabular}

* Significant values.

According to Rohde (1993), an increase in the number of parasites allied to increased length and/or age of the host may be the reason for the cumulative effect of parasites with a long lifespan. This process is more common for ectoparasites with direct transmission, and big fish that have larger gill cavity and body surface, which could harbour many parasites. Buchmann and Lindestron (2002) demonstrated that the magnitude of parasitism is positively related to the size of the host, increasing throughout its life. Different results for Mymarothecium spp. may be due to different abundances between the fish farms. Analysing the young forms of monogeneans in relation to the length, it was observed that the abundance of this parasite decreases as the host's length increases. Small fish are more susceptible to new infestations.

\section{Infracommunity structure}

According to Bush's importance value (Thul et al. 1985), the community structure of ectoparasites in $C$. macropomum showed that the parasites A. spathulatus, Mymarothecium spp., Notozothecium sp. and L. brinkimanni were dominant in the infracommunities of the fish farms studied. The young forms of Monogenea were co-dominant in the two fish farms and the crustacean P. gamitanae was co-dominant in L204S and subordinate in L180N (table 5).
Table 5 - Classification and Bush importance values (I) of the parasitic fauna in Colossoma macropomun captured in two fish farms (L204S and L180N) in the City of Rolim de Moura between March 2009 and March 2010.

\begin{tabular}{|c|c|c|}
\hline \multirow{2}{*}{$\begin{array}{l}\text { Fish farms } \\
\text { parasites }\end{array}$} & L180N & L204S \\
\hline & I & 1 \\
\hline \multicolumn{3}{|l|}{ Monogenea } \\
\hline Anacanthorus spathulatus & 45.58 & 27.69 \\
\hline Mymarothecium spp. & 12.4 & 15.31 \\
\hline Notozothecium sp. & 29.49 & 53.14 \\
\hline Linguadactyloides brinkimanni & 12.3 & 3.0 \\
\hline Monogenea young forms & 0.13 & 0.46 \\
\hline \multicolumn{3}{|l|}{ Crustacea } \\
\hline Perulernaea gamitanae & 0.001 & 0.36 \\
\hline
\end{tabular}

The crustacean $P$. gamitanae can cause mortality in the intensive culture of tambaqui. Thatcher and Paredes (1985) described more than 80 parasites feeding on the blood of a juvenile tambaqui. This parasite was recently observed in fish farms in Rolim de Moura, and the species demands special prevention care to avoid its establishment in the fish farms of the city.

\section{Relative condition factor and hepatosomatic and splenosomatic relations}

In this study, Spearman's rank correlation coefficient $(r s)$ correlating $\mathrm{Kn}$ with the abundance of parasitism showed no significant correlation considering both fish farms and all parasite species. The results reflect the low mean abundance of all the species, being less than 12 parasites per sampled host (table 2).

The lack of significant correlation showed that the parasites, in spite of being pathogenic, were not harming the fish to the point of diminishing their $\mathrm{Kn}$.

According to Spearman's rank correlation coefficients (rs) between abundance and HSR, A. spathulatus showed negative correlations $(r=-0.3384, p=0.0199)$ in $\mathrm{L} 180 \mathrm{~N}$, and positive correlations ( $r s=0.4127, p=0.0169)$ in L204S. Mymarothecium spp. and Notozothecium sp. showed positive correlations $(r s=0.5407, p=0.0011$ and $r s=0.5996$, $p=0.0002$, respectively) in L204S. The young forms of monogeneans were positively correlated $(r s=0.3578, p=$ 0.0135 ) to HSR in L180N.

Studies on the biometric variables of the liver are scarce. For Brazilian species, assessment in relation to the hepatosomatic variable was associated with the life cycle of the fish. Tavares-Dias et al. (2008) investigated the degree of healthiness from the values of Kn, HSR and SSR in juveniles of Brycon amazonicus Spix \& Agassiz 1982 and C. macropomum in the Amazon and concluded that these fish were in a good state of health. 
By analysing Spearman's rank correlation coefficients $(r s)$ using the SSR and the abundance of parasitism for 80 hosts, there was a positive correlation $(r s=0.3634, p=0.0120)$ in $\mathrm{L} 180 \mathrm{~N}$, and a negative correlation $(r=-0.3669, p=0.0356)$ in L204S, only for the species $L$. brinkinanni. The negative correlation was expected, since parasitism itself causes damage to the host. However, due to the low abundance, it was not possible to observe intense pathology considering most species of parasites.

According to Tavares-Dias et al. (2008), there is a correlation between the weight of the liver and spleen and the length of healthy hosts, and the spleen may vary according to age, the physiological state of the animal, the environment, sex and reproductive cycle or in stressful situations.

Tavares-Dias et al. (2008) analysed HSR, SSR and Kn in relation to parasitism in fish from natural environments, and found no alterations in the spleen of infected fish. The same authors argue that these results can occur because parasitic infestations are not high enough to induce anaemia or severe leukocyte responses in infected fish, which may be occurring in this study. According to Lizama et al. (2007), knowledge of ecological relationships between the parasites, their hosts and environment is extremely important in order to avoid significant loss in the properties.

\section{CONCLUSION}

These two fish farms presented values of $\mathrm{pH}$, alkalinity $\left(\mathrm{mgl}^{-1}\right)$, total hardness $(\mathrm{ppm})$, dissolved oxygen $\left(\mathrm{mgl}^{-1}\right)$, transparency $(\mathrm{cm})$, ammonia $\left(\mathrm{mgl}^{-1}\right)$ and temperature $\left({ }^{\circ} \mathrm{C}\right)$ for good tambaqui culture (at adequate levels for the development of tambaqui).

We observed a wide range of ectoparasites on the gills of tambaqui; seven species were recorded: the monogeneans A. spathulatus, Mymarothecium sp. 1, Mymarothecium sp. 2, M. viatotum, Notozothecium sp., L. brinkimanni and the crustacean P. gamitanae.

The parasite fauna was the same in both fish farms and the communities were similar, very prevalent but not abundant.

The absence of significant correlation shows that the parasites, although being pathogenic, were not harming the fish to the point of diminishing the Kn.

Studies related to the ecological relations between hosts and parasites are very useful tools to prevent several diseases.

Despite the $100 \%$ prevalence of parasitism, good water quality in the two fish farms contributed to the parasitic infracommunities that were not abundant enough to cause changes in the values of $\mathrm{Kn}, \mathrm{HSR}$ and SSR, which is an important factor for the development of the fish.

\section{ACKNOWLEDGEMENTS}

The authors thank the owners of the fish farms, Mr Clovis Luiz Manthai and Mr Osmar Pauli, for permission to use the fish culture for research.

\section{REFERENCES}

Araujo-Lima, C.A.R.; Goulding, M. 1997. Os frutos do tambaqui: ecologia, conservação e cultivo na Amazônia. Sociedade Civil Mamirauá, MCT-CNPq, Tefé, Brazil. 186 pp.

Aride, P.H.R., Roubach, R.; Val, A.L. 2004. Water pH in central Amazon and its importance for tambaqui (Colossoma macropomum) culture. World Aquaculture 35(2): 2427.

Békési, L. 1992. Evaluation of data on ichthyopathological analyses in the Brazilian Northeast. Ciência e Cultura 44: 400-403.

Benetton, M.L.F.N.; Malta, J.C.O. 1999. Morfologia dos estágios de náuplius e copepodito I de Perulernaea gamitanae Thatcher \& Paredes, 1985 (Crustácea: Cyclopoida: Lernaeiadae), parasita do tambaqui Colossoma macropomum (Cuvier, 1818), (Osteichthyes: characidae) cultivados em laboratório. Acta Amazonica 29 (1): 97-121.

Buchmann, K.; Lindenstrom, T. 2002 Interactions between monogenean parasites and their fish hosts. International Journal for Parasitology, 32: 309-319.

Bush, A.O.; Lafferty, K.D.; Lotz, J.M.; Shostak, A.W. 1997. Parasitology meets ecology on its own terms: Margolis et al. revisited. Journal of Parasitology, 83(4): 575-583.

Eiras, J.C., Takemoto, R.M. \& Pavanelli, G.C. 2006 Métodos de estudo e técnicas laboratoriais em parasitologia de peixes. 2ed, EDUEM, Maringá, PR 199. pp.

Eiras, J.C.; Takemoto, R.M.; Pavanelli, G.C. 2010. Diversidade dos parasitos de peixes de água doce do Brasil. Clichetec, Maringá; 333 pp.EMATER, Associação de Assistência Técnica e Extensão Rural do Estado de Rondônia. 2006, Sistema de Produção do Tambaqui, 2 ed. Porto Velho. 38 pp.

EMBRAPA, Empresa Brasileira de Pesquisa Agropecuária 2011. Modified from http://www.cnpgl.embrapa.br/nova/silpf/app. images/mapas/ro.jpg (accessed 14 May 2011).

EMATER, Associação de Assistência Técnica e Extensão Rural do Estado de Rondônia 2006. Sistema de Produção do Tambaqui, 2ed (revisada, atualizada e ampliada). Porto Velho. 36pp.

Fernandes, L.C.; Guimarães, S.C.P. 2002. Atlas geoambiental de Rondônia. v. 2. SEDAM, Porto Velho. 151 pp.

Ferraz, E.O. 1995. Studies on parasites of ornamental fish from South America with particular reference to their pathogenicity and potential for transfaunation. Ph.D. Thesis, Institute of Aquaculture, University of Stirling, Scotland. 410 pp.

Fischer, C.; Malta, J.C.O.; Varella, A.M.B. 2003 A fauna de parasitos do tambaqui, Colossoma macropomum (Cuvier, 1818) (Characiformes: Characidae) do médio rio Solimóes (AM) e do baixo rio Amazonas (PA) e seu potencial como indicadores biológicos. Acta Amazonica, 33(4): 651-662.

Garcia, L.O; Copatti, C.E.; Wachholz, F.; Pereira Filho, W.; Baldisserotto, B. 2008. Freshwater temperature in the state of 
Rio Grande do Sul Southern Brazil, and its implication for fish culture. Neotropical Ichthyology, 6(2): 275-281.

Ghiraldelli, L.; Martins, M.L.; Jeronimo, G.T; Yamashita, M.M.; Adamante, W.B.; 2006. Ectoparasites Communities from Oreochromis nilocotis cultivated in the State of Santa Catarina, Brazil. Journal of Fisheries and Aquatic Science 1 (2): 181-190.

Gomes, L.C.; Simões, L.N.; Araujo-Lima, C.A.R.M. 2010. Tambaqui (Colossoma macropomum), p.175-204. In: Baldisserotto, B.; Gomes L.C. (org.). 2010. Espécies nativas para pisciculturas no Brasil. $2^{\circ}$ ed. Ed. Ufms, Santa Maria. 680 pp.

Ismiño-Orbe, R.A; Araujo-Lima, C.A.R.M.; Gomes, L.C. 2003. Excreção de amônia por tambaqui (Colossoma macropomum) de acordo com variaçóes na temperatura da água e massa do peixe. Pesquisa Agropecuária Brasileira 38(10): 1234-1247.

Izel, A.C.U.; Melo, L.A.S. 2004. Criação de tambaqui (Colossoma macropomum) em tanques escavados no Estado do Amazonas. [on-line]. Manaus: Embrapa Amazônia Ocidental. available in: http://www.infoteca.cnptia.embrapa.br/bitstream/ doc/674621/1/Doc32.pdf (accessed 15 August 2011)

Kritsky, D.C., Boeguer, W.A; Van Every, L.R. 1992. Neotropical Monogenoidea. 17. Anacanthorus Mizelle and Price, 1965 (Dactylogyridae, Anacanthorinae) from Characoid fishes of the Central Amazon. Journal of the Helminthological Society of Washington, 59(1): 25-51.

Le Cren, E.D. 1951. The length-weight relationship and seasonal cycle in gonad weight and condition of perch Perca fluviatilis. Journal of Animal Ecology, 20: 201-219.

Lizama, M. de Los A.P.; Takemoto, R.M.; Ranzani-Paiva, M.J.T.; Ayroza, L.M.S.; Pavanelli, G.C. 2007. Relação parasitohospedeiro em peixes de pisciculturas da regiáo de Assis, Estado de São Paulo, Brasil. 1. Oreochromis niloticus (Linnaeus, 1757). Acta Scientiarum Biological Science 29(2): 223-231.

Malta, J.C.O.; Varella, A.M.B. 2000. Argulus chicomendesi sp. n. (Crustacea: Argulidae) parasita de peixes da Amazônia Brasileira. Acta Amazonica 30(1): 481-498.

Martins, M.L.; Azevedo, T. M.P., Ghiraldhelli, L.; Bernardi, N. 2009. Can the parasitic fauna on Nile tilapias be affected by different production systems? Annals of the Brazilian Academy of Sciences 82(2): 493-500.

Morais, A.M.; Varella, A.M.B.; Villacorta-Correa, M.A.; Malta, J.C.O. 2009. A fauna de parasitos em juvenis de tambaqui Colossoma macropomum (Cuvier 1818) (Characidae: Serrasalminae) criados em tanques-redes em lago de várzea da Amazônia Central. Biologia Geral e Experimental., 9(1): 14-23, 30.xii.

Paperna, I. 1963. Some observations on the biology and ecology of Dactylogyrus vastator in Israel. Bamidgeh Bulletin of Fish Culture in Israel, 5: 828.

Pavanelli, G.C.; Eiras, J.C.; Takemoto, R. M. 1998. Doenças de peixes: profilaxia, diagnóstico e tratamento. Eduem, Maringá. 268 pp.

Rohde, K. 1993. Ecology of marine parasites: an introduction to marine parasitology. 2nd ed. CAB International, Wallingford, Oxon, UK. 298 pp.

Saint-Paul, U. 1984. Physiological adaptation hypoxia of a neotropical characoid fish Colossoma macropomum, Serrasalmidae. Environmental Biology of Fishes, 11: 53-62.

Tavares-Dias, M.; Marcon, J.L.; Lemos, J.R.G.; Fim, J.D.I.; Affonso E.G.; Ono, E.A. 2008 Índices de condição corporal em juvenis de Brycon amazonicus (Spix \& Agassiz, 1829) e Colossoma macropomum (Cuvier, 1818) na Amazônia. Boletim do Instituto de Pesca 34, 197-204.

Tavares-Dias, M.; Martins, M.L.; Moraes, F.R.; 2001. Fauna parasitária de peixes oriundos de "pesque-pague" do município de Franca, São Paulo, Brasil. I. Protozoários. Revista Brasileira de Zoologia 18 (Suppl. 1), 67-79.Thatcher, V.E. 2006. Amazon fish parasites. 2nd ed. Pensoft Publishers: Sofia-Moscow. 508 pp.

Thatcher, V.E.; Paredes, V. 1985. A parasitic copepod Perulernaea gamitanae gen. et sp. nov. (Cyclopoida: Lernaeidae), from the nasal fossae of a Peruvian Amazon food fish. Amazoniana, 9(2), 169-175.

Thatcher, V.E. 2006. Amazon Fish Parasites. 2nd. ed., Pensoft Publishers, Sofia-Moscow. 508 pp.

Thul, J.E.; Forrester, D.J.; Abercrombie, C.L. 1985. Ecology of parasitic helminthes of wood ducks, Aix sponsa, in the Atlantic Flyway. Proceedings of the Helminthological Society of Washington, 52 (2): 297-310.

Recebido em: 08/07/2011

Aceito em: 28/09/2011 
